\title{
The role of Toll-like receptor signaling pathways in cerebrovascular disorders: the impact of spreading depolarization
}

\author{
Rezan Ashayeri Ahmadabad ${ }^{1,2}$, Maryam Khaleghi Ghadiri ${ }^{2}$ and Ali Gorji ${ }^{1,2,3,4,5^{*}}$
}

\begin{abstract}
Cerebral vascular diseases (CVDs) are a group of disorders that affect the blood supply to the brain and lead to the reduction of oxygen and glucose supply to the neurons and the supporting cells. Spreading depolarization (SD), a propagating wave of neuroglial depolarization, occurs in different CVDs. A growing amount of evidence suggests that the inflammatory responses following hypoxic-ischemic insults and after SD plays a double-edged role in brain tissue injury and clinical outcome; a beneficial effect in the acute phase and a destructive role in the late phase. Toll-like receptors (TLRs) play a crucial role in the activation of inflammatory cascades and subsequent neuroprotective or harmful effects after CVDs and SD. Here, we review current data regarding the pathophysiological role of TLR signaling pathways in different CVDs and discuss the role of SD in the potentiation of the inflammatory cascade in CVDs through the modulation of TLRs.
\end{abstract}

Keywords: Stroke, Spreading depolarization, Toll-like receptors, Subarachnoid hemorrhage, Inflammatory mediators, Chemokines, Brain

\section{Introduction}

Cerebrovascular diseases (CVDs) include conditions and disorders that affect blood supply to the brain [1]. CVDs largely include transient ischemic attack (TIA), acute ischemic stroke (AIS), intracerebral hemorrhage (ICH), subarachnoid hemorrhage ( $\mathrm{SAH})$, cerebral venous sinus thrombosis (CVST), arteriovenous malformation, and numerous inherited cerebral vasculopathies [2]. Among these, AIS is the second leading cause of death and third leading cause of disability worldwide [3, 4].

Numerous studies indicate that inflammation can be induced by hypoxia. It has been shown that inflammatory markers, like interleukin-6 (IL6) and C-reactive protein, increased in healthy climbers at the altitude of

\footnotetext{
* Correspondence: gorjial@uni-muenster.de

'Shefa Neuroscience Research Center, Khatam Alanbia Hospital, Tehran, Iran ${ }^{2}$ Department of Neurosurgery, Westfälische Wilhelms-Universität Münster, Münster, Germany

Full list of author information is available at the end of the article
}

more than $3400 \mathrm{~m}$ [5], in organ graft patients [6], and in mice with short-term exposure to low oxygen environments [7]. Complete or partial disruption of regional cerebral blood flow (rCBF) results in an ischemic insult, which through different mechanisms finally lead to cell injury and death [8]. Cell damage due to ischemic injury induce a local inflammation in response to endogenous molecules which are released from cell debris, which in turn exacerbate the ischemic injury [9]. The activation of resident microglia, the recruitment of macrophages and leukocytes, and the production of pro-inflammatory cytokines and other inflammatory mediators are the main part of local inflammatory responses to ischemic injury [10]. Under ischemic conditions, ischemicinduced mediators provoke transcription of various genes, such as nuclear factor $\kappa \mathrm{B}(\mathrm{NF}-\kappa \mathrm{B})$ and Toll-like receptors (TLRs), which play a crucial role in the modulation of immune system [7, 11]. NF- $\mathrm{kB}$, the main transcription factor of TLRs, activates via the secretion of 
various cytokines and chemokines [12]. The activation of TLRs pathway triggers various inflammatory processes. TLRs are cell membrane receptors with a fundamental role in the recognition of pathogen molecules, such as bacterial lipopeptides, flagellin, and lipopolysaccharides $[10,13]$. The activation of TLRs can also be modulated in response to different types of cytokines, like chemokines, interferons, and interleukins, which are presented in the vicinity of ischemic brain tissue [14].

Accumulating evidence suggest that TLRs play a crucial role in the pathogenesis of AIS [15, 16], ICH $[17,18]$, and $\mathrm{SAH}$ [19]. TLRs activation following ischemic insults could be pathogenic or neuroprotective, depending on the context. TLRs signals, via the recruitment of specific molecules, lead to the activation of inflammatory cytokines that can worsen the ischemic insult [20]. In contrast, activation of TLRs signaling pathway before cell damage can protect the cells from further damage, a process called preconditioning [21]. Moreover, several studies have shown the modulatory effects of TLRs agonists/antagonists on the pathophysiologic procedures of different CVDs [21-24]. Modulation of various TLRs subtypes, particularly TLR3 and TLR4, could affect CVD-induced brain injury and their neurological deficits. The role of TLR4/NF- $\mathrm{BB}$ signaling pathway in ICH has been reported [25]. It has been suggested that drugs target TLR signaling pathways that offer novel opportunities for exerting neuroprotective effects against various CVDs [14, 21].

Spreading depolarization (SD) is a transient or sustained negative shift of the DC potential, which propagates over the cerebral grey matter at a slow rate of a few $\mathrm{mm} / \mathrm{min}$ [26-28]. The cerebral blood flow response to SD consists of at least three distinct elements: an initial transient hypoperfusion, a dominant transient hyperemia, and a long-lasting oligemia [29]. The rCBF response to SD modulates by the metabolic condition of the tissue $[29,30]$. In patients, terminal SD occurs during cardiac arrest $[31,32]$ and the development of brain death [33]. SD occurs in patients suffering from various CVDs, such as AIS [34, 35], ICH [36], and SAH [35, 37]. In fact, SD occurs in the ischemic core during the development of focal ischemic insults [38]. In focal cerebral ischemia, SD not only occurs in the ischemic core and penumbra but also they can invade the adequately perfused surrounding tissue. SD wave changes along its spread from the core to the penumbra to the surrounding tissue from a long-lasting harmful to a short-lasting harmless event [39]. The SD continuum is characterized by the continuity of depolarization waves that convert from persistent to progressively shorter ones as they spread from an initial ischemic event. Within a few minutes of an acute severe ischemic event, the onset of persistent depolarization leads to the breakdown of ion homeostasis and induction of cytotoxic edema [39]. The pharmacological profile alters along the SD continuum. In the ischemic periphery, SD can be inhibited by the Nmethyl-D-aspartate (NMDA) receptor antagonists [40].On the contrary, blocking of NMDA receptor is progressively less capable of ceasing SD in increasingly more ischemic tissue [41].

The SD continuum can exacerbate the ischemic insults due to the induction of the cytotoxic edema of the brain's grey matter and lead to further inflammatory responses in CVDs [42]. The association between the occurrence of SD in CVDs and poor clinical outcomes has led to the nomination of SD as a potential biomarker for assessment of brain injury [43]. SD induces a severe vasoconstriction that under specific conditions leads to an instantaneous hypoperfusion (spreading ischemia) and exacerbates cell injury and death [44-46]. It is important to note that SD induces an increase in cerebral blood flow that is variably followed by a mild decrease in normal tissue. The predominant response is thus an increase rather than a decrease in such tissue. By contrast, SD can induce a severe decrease of cerebral blood flow variably followed by an increase of cerebral blood flow in tissue at risk (= inverse hemodynamic response or spreading ischemia) $[47,48]$. Thus, the predominant response is a decrease in tissue at risk. Furthermore SD initiates inflammatory responses that contribute to cell damage and death in juvenile rats mainly via the modulation of astrocytes [44, 49-51]. However, according to another study that were done in adult rats, SD can only induce irreversible neuronal injury in the tissues at risk [52]. This data also confounding but reveals that SDs could be harmful to juvenile neuronal tissue under specific slice preparation that is differ from what has been recognized about their effect on adult neuronal tissue $[50,51]$. Furthermore, it has been shown that repetitive high mobility group box 1 (HMGB1)-TLR2/4 signaling pathway is a mediator of repetitive SD-induced microglial activation, which may be contributing to neuroinflammatory responses following SD [53]. In this review, after a brief overview of the TLR signaling pathways, we accumulate all evidence regarding the implications of TLRs in CVDs. Then, we discuss the role of SD in the potentiation of the inflammatory cascade in CVDs through the modulation of TLRs.

\section{General aspects of Toll-like receptor signaling pathways}

TLRs are transmembrane receptors that have critical role not only in innate immune response, but in inflammation and immune cell regulation as well as cell survival and proliferation [54-57]. To date, 13 TLRs have been recognized, including TLR1 through TLR13. However, human cells do not express the last 3 of them [58]. As shown in Fig. 1, TLR1, TLR2, TLR4, TLR5, and 
TLR6 are localized in the plasma membrane, and TLR3, TLR7, TLR8, and TLR9 are expressed within endosomes [59]. TLRs are expressed in neurons, microglia, astrocytes, oligodendrocytes, and neural stem cells [60]. TLRs detect exogenous molecules, like bacterial lipopeptides, flagellin, lipopolysaccharides, double-stranded DNA (dsDNA), double-stranded RNA (dsRNA), and singlestranded RNA (ssRNA) as well as endogenous molecules called damage-associated molecular patterns (DAMPs) released from injured cells [11]. TLRs are activated through binding of pathogen-associated molecular patterns (PAMPs), which are entirely expressed by microbial pathogens, and DAMPs that are host molecules released from injured cells [61]. This incident will result in a cascade of events through two main TLR-associated signaling pathways that lead to activation of different transcription factors. The first one is myeloid differentiation primary response 88 (MyD88), which in one hand, acts as an adapter protein to activate NF- $\mathrm{kB}$ via almost all TLRs, except TLR3, and on the other hand, activates and interacts with transcription factor IRF-7. The latter pathway forms a bridge between the MyD88-dependent and independent pathways. Furthermore, TLR9-MyD88IRF7 signaling has a critical implication in dendritic cellbased immune responses, as it promotes robust type I interferon induction in these cells [62]. The second pathway is TLR-domain-containing adapter-inducing interferon- $\beta$ (TRIF) that is associated with TLR3 and TLR4 to activate NF- $\mathrm{kB}$ and interferon regulatory factor (IRF) [63]. TLR4 activates both the MyD88-dependent and the MyD88-independent pathways. NF- $\mathrm{kB}$ is a transcription factor leading to produce pro-inflammatory cytokines (TNF $\alpha$, IL1, IL6, and IL12), whereas IRF is an immunomodulatory transcription factor which leads to the production of type I interferons (IFN- $\alpha / \beta)$ and develops an innate antiviral response [24]. Another important ligand for TLRs are HMGB1, which is a nuclear protein secreted by both immune cells and necrotic cells after hypoxic-ischemic (H-I) damage. HMGB1 mostly binds to TLR2 and TLR4 to induce inflammation through NF-kB signaling pathway [64]. Although HMGB1 has been proposed as a target for cancer

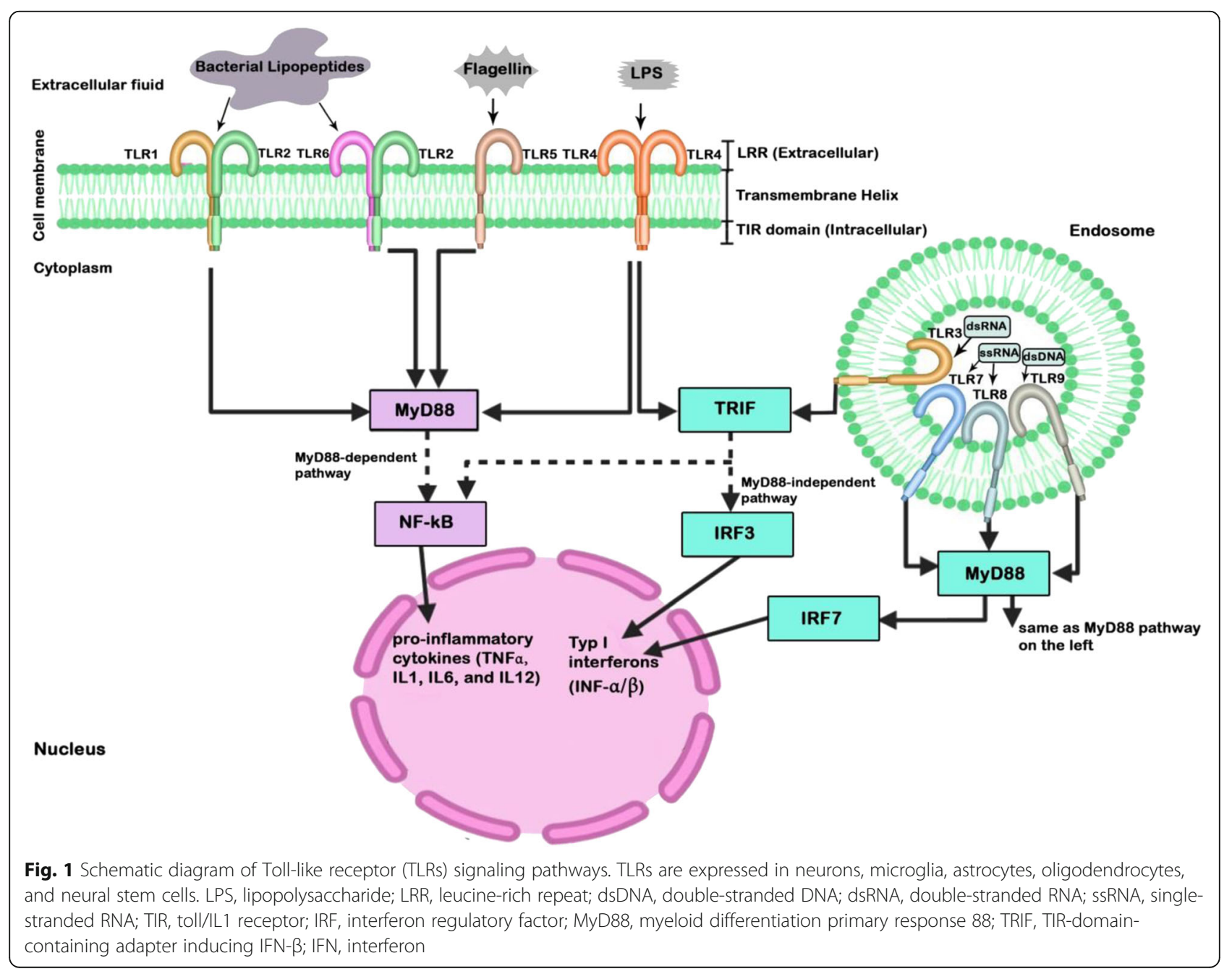


therapy, increasing evidence suggests its possible biphasic role in CVDs [65].

\section{The role of Toll-like receptors in cerebral vascular diseases}

TLR signaling pathways implicated in the pathogenesis of several neurological disorders, such as multiple sclerosis [66], epilepsy [67], Alzheimer's disease [68, 69], Huntington's disease [70], Parkinson's disease [71], Lewy body dementia [72], amyotrophic lateral sclerosis [73, 74], migraine headache [75], the central nervous system infections [76], and traumatic brain injury [77]. Modulation of TLRs has been shown to contribute to CVDs, including AIS, ICH, SAH, and CVST (Table 1).

The role of Toll-like receptors in acute ischemic stroke Atherosclerosis, which is the main cause of AIS, is an inflammatory process with immune response during initiation and progression of the disease [86]. The endothelium is a main contributor of vascular integrity due to its antiinflammatory property. Evidence shows that endothelial dysfunction is the first measurable step of atherothrombosis formation [87]. In this regard, TLRs and particularly TLR4, which are found in the endothelial cell plasma membrane, have a critical role in the induction and the evolution of atherosclerosis [87-89]. Various cell types in the atherosclerotic vessel wall express TLR4, including neutrophils, macrophages, endothelial cells, fibroblasts, and dendritic cells [90-93]. Activation of TLR4 produce cytokines, which influence multiplication and migration of vascular smooth muscle cells and higher expression levels of MMP2 and MMP-9 [94]. Monocytes and T lymphocytes will be recruited to the arterial TLR4 ligands during the initial phases of atherogenesis. This requires expression of adhesion molecules on the endothelium, which regulates transcription of TLRs through modulation of NF- $\mathrm{KB}$ values [94].

AIS activates the TLR signaling pathway, leads to the production of a plenty of inflammatory mediators, and triggers secondary inflammation damages. However, a mild ischemic insult can lead to TLR ischemic tolerance and decrease brain injury through the inhibition of the TLR4/NF- $\mathrm{kB}$ and TLR2 signaling pathway and the activation of IRF3 signaling: a process points to the beneficial effect of MyD88 signaling pathway [95]. In another word, exposure to a minor cerebral ischemia enhances neuronal tolerance to subsequent injury and shifts cellular signaling from NF-kB pathway to IRF3, which produces IFN-b, one of the final products of IRF3 signaling pathway with neuroprotective effects. Administration of a low dose of TLR2, TLR3, TLR4, TLR7, or TLR9 ligand before $\mathrm{H}-\mathrm{I}$ insult promotes neuroprotection and reduces

Table 1 Brief overview of the association between Toll-like receptors and cerebral vascular diseases

\begin{tabular}{|c|c|c|c|c|}
\hline \multicolumn{5}{|l|}{ CVDs } \\
\hline TLRs & AIS & $\mathrm{ICH}$ & $\mathrm{SAH}$ & CVST \\
\hline TLR2 & $\begin{array}{l}\text { Moderator for leukocytes and microglial } \\
\text { infiltration and neuronal death }[78,79]\end{array}$ & - & & $\begin{array}{l}\text { Activated in } \\
\text { antiphospholipid } \\
\text { syndrome [80] }\end{array}$ \\
\hline TLR3 & $\begin{array}{l}\text { Neuroprotective and anti-inflammatory } \\
\text { effects on SD-induced neuroinflammation [63] } \\
\text { Ischemic tolerance induction by TLR3 ligand } \\
\text { poly I:C preconditioning through type I IFN } \\
\text { signaling [81] }\end{array}$ & $\begin{array}{l}\text { Neuroprotective and } \\
\text { anti-inflammatory } \\
\text { effects on SD-induced } \\
\text { neuroinflammation } \\
{[21,82]}\end{array}$ & & \\
\hline TLR4 & $\begin{array}{l}\text { Neuroprotective effect by preconditioning } \\
\text { through suppression of cytotoxic TNFa, } \\
\text { increasing IRFs and production of type I } \\
\text { interferons [78, 79] } \\
\text { Induction and evolution of atherosclerosis } \\
\text { through NF-KB pathway that produce } \\
\text { inflammation }[78,79]\end{array}$ & $\begin{array}{l}\text { Increasing levels of } \\
\text { inflammatory } \\
\text { factors, DNA damage, } \\
\text { and neuronal } \\
\text { degeneration in } \\
\text { perihematomal } \\
\text { region [82] }\end{array}$ & $\begin{array}{l}\text { Activation by Heme } \\
\text { product through the } \\
\text { MyD88 and TRIF } \\
\text { pathways [83] }\end{array}$ & $\begin{array}{l}\text { Activated in } \\
\text { antiphospholipid } \\
\text { syndrome } \\
\text { [80] }\end{array}$ \\
\hline TLR7 & $\begin{array}{l}\text { Neuroprotective effect by preconditioning with } \\
\text { TLR7 ligand, gardiquimod, reduction in infarct } \\
\text { size, and a better functional outcome } \\
\text { independent of TNFa and dependent on } \\
\text { interferon [84] }\end{array}$ & - & & \\
\hline TLR8 & $\begin{array}{l}\text { Activation causes worsening of ischemic brain } \\
\text { injury [85] }\end{array}$ & - & & - \\
\hline TLR9 & $\begin{array}{l}\text { Neuroprotective effect by preconditioning } \\
\text { through suppression of cytotoxic TNFa, } \\
\text { increasing IRFs, and production of type I } \\
\text { interferons [20] }\end{array}$ & - & & $\begin{array}{l}\text { Deletion is associated } \\
\text { with larger venous } \\
\text { thrombosis and increased } \\
\text { leukocyte infiltration [80] }\end{array}$ \\
\hline
\end{tabular}

AIS acute ischemic stroke, APS antiphospholipid syndrome, ICH intracerebral hemorrhage, CVD cerebral vascular disease, $C V S T$ cerebral venous sinus thrombosis, $S A H$ subarachnoid hemorrhage, SD spreading depolarization, TNF tissue necrosis factor, IFNA interferon-a/ $\beta$ receptor, TLR Toll-like receptor 
the infarct volume in animal experimental models [20]. Systemic administration of low doses of lipopolysaccharide (LPS), a TLR4 ligand, a cell wall component of gram-negative bacteria, to hypertensive rats caused tolerance to subsequent brain ischemia induced by middle cerebral artery occlusion [96]. Several other animal models of AIS have also revealed the LPS-induced tolerance to brain ischemia [97-99]. The mechanism by which LPS enhances the tolerance to cerebral ischemia could be attributed to the suppression of cytotoxic TNF $\alpha$ signaling following AIS. Once the TLRs reprogrammed, their response to subsequent brain ischemia could be increasing IRFs and production of type I interferons. Based on a similar mechanism, TLR9 ischemic tolerance following stimulation by cytosine-guanine oligodeoxynucleotides (CpG-OdN) exhibited the neuroprotective effect [100-102]. CpG-OdN inhibits cerebral ischemic injury and reduces the lesion volume via a PI3K/Akt-dependent pathway [103]. Moreover, the role of TNF $\alpha$ signaling in the preconditioning with TLR ligands has been demonstrated. Administration of TNF $\alpha$ itself reprogrammed the cell structure in favor of the remodeling of the inflammatory response to the subsequent ischemia [100-102]. Interestingly, CpG-OdNinduced preconditioning in a mouse model of AIS changed the genomic response to stroke in the circulating leukocytes and the brain cells [102]. In addition, it has been shown that TLR2 ischemic tolerance may attenuate the brain lesion after AIS. Inhibition of TLR2 signaling pathway regulates leukocytes and microglial infiltration and the subsequent neuronal death after mild AIS [78, 87, 104, 105]. Inhibition of TLR4 could attenuate the inflammation and H-I damages through blockade of tissue-type plasminogen activator-induced hemorrhagic transformation [106] as well as enhancement of the ratio of alternative neutrophils [15]. It has been shown that TLR4-deficient mice have significantly less tolerance to $\mathrm{H}-\mathrm{I}$ insults than wild-type mice, possibly via the lesser expression of $\mathrm{TNF} \alpha$, cyclooxygenase-2 (COX-2), and NF- $\mathrm{KB}$ [107]. An experimental study has shown that the western diet provokes TLR4-induced endothelial dysfunction and suggesting a potential role of TLR4-related inflammation in increasing the risk of AIS [108].

One of the most important ligand for TLRs, especially TLR2 and TLR4, is HMGB1. Both experimental and clinical studies indicate that HMGB1 is released from injured brain tissues as well as activated microglia within the ischemic tissues and activates an early inflammatory response after AIS [109]. HMGB1signals via TLR2 and TLR4 signaling activate the NF- $\mathrm{KB}$ pathway and induce a proinflammatory response [110]. Several studies have shown that plasma levels of HMGB1 increase in ischemic stroke and correlate with poor outcome [111-113].
Despite the potential inflammatory role of HMGB1 in the acute phase of stroke, there is some evidence in favor of its immunomodulatory action in the delayed phase [65]. HMGB1 has been suggested as a potential biomarker for prediction of the AIS prognosis [110].

In addition to TLR4 and TLR2, evidence suggests the implication of TLR7, TLR8, and TLR9 in the neuroinflammtory responses induced by $\mathrm{H}-\mathrm{I}$ insults. Application of the TLR7 agonist Gardiquimod before middle cerebral artery occlusion in mice reduces infarct volume as well as functional deficits: a neuroprotective effect independent of TNF and dependent on interferon [84]. A greater expression of TLR7 and TLR8 was associated with a higher inflammatory response and a worse outcome in patients with AIS. The expressions of TLR7 and TLR8 were correlated with IL6 and IL1 $\beta$ values during the first week of AIS. In addition, the expression of TLR8 was correlated with cerebral infarct volumes [85]. Furthermore, it has been shown that exogenous preconditioning with TLR2, TLR4, and TLR9 ligands prior to the occurrence of AIS provides neuroprotection [114].

\section{The role of Toll-like receptors in intracerebral hemorrhage}

Recent investigations have shown that inflammation to some degree is responsible for secondary brain damage after ICH [25]. It has been suggested that the activation of TLRs, particularly TLR4, contributes to the microglial phagocytosis and consequently to the development of inflammatory brain injury in $\mathrm{ICH}$ [115]. Induction of $\mathrm{ICH}$ in TLR4-deficient transgenic mice has been revealed a significant reduction of perihematomal inflammation and decreased recruitment of inflammatory cells associated with the promotion of functional recovery, pointing to the role of TLR4 in poor functional outcomes in ICH [85]. In addition to TLR4, higher expression of TLR2 in both monocytes and neutrophils is associated with a larger lesion volume and poor outcomes in patients with ICH [116]. Repetitive intraperitoneal administration of TAK-242, a TLR4 antagonist, in an ICH mouse model remarkably reduced brain water capacity, peripheral inflammatory cell infiltration, the values of inflammatory mediators, and neurological deficit scores. The expressions of TLR4 downstream signaling molecules, including MyD88, TRIF-inducing interferon-beta I $\mathrm{\kappa B} \alpha$, and $\mathrm{NF}-\kappa \mathrm{B}$, were significantly downregulated in these mice [25].

Iron plays a harmful role in the pathogenesis of $\mathrm{ICH}$ and causes oxidative damage, impaired cognitive function, and poor prognosis [117]. Heme, a component of hemoglobin, acts on TLRs and leads to downward activation of NF- $\mathrm{KB}$ signaling, promotes inflammation, and aggravate $\mathrm{ICH}$-induced neurological deficit $[25,82]$. Heme-induced brain inflammatory damages could be 
initiated by the activation of microglia and subsequent release of proinflammatory mediators [118]. Hemoglobin is a strong activator of microglia through activation of TLRs [18]. Hemoglobin induces inflammatory responses following ICH via assembly of TLR2/TLR4 heterodimers, which is a MyD88-dependent process [119]. Heme oxygenase knockout mice have shown a significant decrease in microglia activation, free radical levels, and leukocyte infiltration after ICH [120]. TLR4- and MyD88-deficient mice exhibited an improved brain iron efflux after $\mathrm{ICH}$, and application of a TLR4 antagonist significantly reduced brain iron values associated with promotion of cognitive functions [121]. Sparstolonin B, a Sparganium stoloniferum derivative that selectively inhibits TLR2/TLR4, could reduce secondary inflammatory injury after ICH. Sparstolonin B dose dependently inhibited NF-kB activity through TLR2/TLR4 heterodimer formation and attenuated inflammation after ICH [122]. Furthermore, it has been shown that inflammatory injury of the choroid plexus epithelium due to activation of TLR4-NF- $\mathrm{kB}$ signaling pathways contributes to increased secretion of cerebrospinal fluid following intraventricular hemorrhage [123].

The activation of TLRs can also interact with the downstream spleen tyrosine kinase (Syk) and trigger the release of several inflammatory cytokines, such as IL-1 $\beta$ [124]. This pathway plays a role in traumatic brain injury [125], AIS [126, 127], and ICH [128]. Inhibition of the macrophage-inducible C-type lectin/Syk pathway decreases the release of proinflammatory cytokines and attenuates neurological deficits after ICH [128].

\section{The role of Toll-like receptors in subarrachnoid hemorrhage}

Rupture of saccular aneurysms accounts for the majority of SAH, although the reason for non-aneurysmal SAH is divergent [129]. Hypothesis for the role of inflammation in SAH arises from several investigations, which focused on vasospasm as the main mechanism for the delayed neurologic deficit. As the delayed ischemic neurologic deficit after SAH can occur independently of angiographic vasospasm, it was suggested that the other mechanisms, such as neuroinflammation, may contribute to this distinctive syndrome of cerebral ischemia [130]. Experimental studies have revealed an upregulation of TLR4-NF-kB signaling pathway in early brain injury following SAH [131]. Toll-like receptor signaling and NF- $\mathrm{KB}$ transcription factor binding sites were significantly enhanced after SAH [132]. Furthermore, experimental studies revealed a correlation between the upregulation of TLR4 with the development of cerebral vasospasm after SAH [133]. Enhancement of TLR4 expression on the endothelial cell layer in the wall of the human cerebral aneurysm has been suggested that TLR4 may play an important role in the formation of brain aneurysm [134, 135]. Tenascin-C, a matricellular protein, initiates a severe cerebral arterial constriction following SAH [19]. Application of Tenascin-C enhances the expression of TLR4 in the smooth muscle cell layer of the affected cerebral artery and increases the SAHinduced subarachnoid as well as systemic inflammatory responses [19]. Administration of TLR4 antagonist LPSRS inhibits Tenascin-C-induced cerebral vasospasm and upregulation of TLR4 in rats [136]. Dendritic cells, antigen-presenting cells that regulate the adaptive immune response, express several TLRs. The frequency of myeloid dendritic cells producing TNF- $\alpha$ after application of TLR-3 agonist poly I:C significantly decreased in the SAH patients. In addition, myeloid dendritic cells producing administration of TLR-3 and 4 agonists decreased in the SAH patients compared to healthy subjects [137].

Common mechanisms may underlie the induction of inflammatory processes after ICH and SAH. The breakdown of hemoglobin and the release of heme after SAH could lead to brain inflammatory injury. Heme activates TLR4-induced neuroinflammatory process through the MyD88 and TRIF pathways [118]. Microglia and the TLR4 pathway may play an important role in vasospasm and neuronal apoptosis after SAH. Using TLR4, TRIF, and MyD88 knockout mice, it has been shown that the activation of TLR4-MyD88 pathway is essential for neuronal apoptosis and vasospasm during the early phase of $\mathrm{SAH}$, whereas neuronal damage and vasospasm in the late phase of SAH were TLR4-TRIF dependent. Microglial cells play a crucial role in SAH-induced vasospasm in both the early and late phases of SAH [83]. The effects of two selective TLR4 inhibitors on SAH-induced disruption of the blood rain barrier (BBB) were assessed in a SAH experimental model $[138,139]$. Intracerebroventricular application of these selective TLR4 antagonists, IAXO-102, and TAK-242, in male mice with SAH significantly reduced post-SAH neurological deficits, the $\mathrm{BBB}$ disruption, and brain edema, leading to a better survival rate [139].

Furthermore, it has been suggested that peroxisome proliferator-activated receptor gamma (PPAR- $\gamma$ ) receptors play a modulatory role in SAH-induced inflammatory responses through the TLR4 pathway [140]. Activation of PPAR- $\gamma$ receptors is shown to efficiently inhibit TLR4 pathway [141]. Rosiglitazone, a PPAR- $\gamma$ agonist, inhibited the SAH-induced inflammatory injury as well as cerebral vasospasm in basilar arteries via suppression of the TLR4 signaling pathway in an animal experimental SAH model [142]. Pannexin-1 channels, a member of gap junction proteins involved in the innate and acquired immune system, could also contribute to the induction of inflammation and cognitive dysfunction of SAH via the TLR2/TLR4/NF- $k B$-mediated signaling 
pathways. Pannexin-1 channels protein gene knockdown significantly reduced the expression values of TLR2/4/ NF- $\mathrm{KB}$ signaling pathway in the neocortex and improved cognitive and memory deficits in a rat SAH model [143].

\section{The role of Toll-like receptors in cerebral venous sinus thrombosis}

The role of TLR9 signaling pathway in venous thrombus resolution was investigated in a mouse model of CVST [144]. It has been found that mice with the deletion of TLR9 had significantly a larger venous thrombosis and increased leukocyte infiltration compared with wild-type mice. Although MyD88 is the intracellular signaling pathway of TLR9, mice lacking MyD88 had no greater venous thrombus resolution than wild-type mice. Application of TLR9 agonist was associated with smaller venous thrombosis in this model. It has been shown that the TLR pathway mainly through TLR2 and TLR4 is activated in patients with antiphospholipid syndrome, suggesting a biomarker role of TLRs in this syndrome [80]. Moreover, a significant rise in the gene expression of TLR2 and TLR4 was observed in peripheral mononuclear cells that mediate antiphospholipid antibodies induced vascular abnormalities. Hence, targeting these receptors as a therapeutic option to prevent the thrombotic effects of antiphospholipid antibodies in antiphospholipid syndrome could be the subject of interest in the future studies.

\section{Contribution of spreading depolarization to inflammatory response following cerebral vascular diseases}

SD was discovered over 75 years ago by Aristides Leão in the course of his investigations on the initiation and propagation of epileptiform burst discharges [145]. Over the past decades, compelling evidence has accumulated to demonstrate the occurrence of SD in the brain of patients suffering from CVDs [29, 146, 147]. Using intracranial recordings, the occurrence of repetitive SD has been shown in patients with AIS [34, 35], ICH [148, 149], and SAH [35, 37, 48]. There are numerous experimental and clinical data suggesting that SD aggravate tissue injury and neurological outcomes of CVDs [150, 151]. The normal response in healthy tissue is a brief increase of $\mathrm{rCBF}$ (spreading hyperemia) followed by a prolonged decrease (spreading oligemia). The altered or pathological response in tissue at risk is a steep and prolonged fall in $\mathrm{rCBF}$ variably followed by a prolonged hyperemia [47, 48, 152-154]. Furthermore, the propagation of SD is associated with an increase of glucose utilization and $\mathrm{O}_{2}$ consumption as well as with marked increases in local energy requirements to restore ion homeostasis [155, 156]. The combinations of reduced rCBF enhanced energy demand, mitochondrial depolarization, and a massive $\mathrm{Ca}^{2+}$ influx as well as $\mathrm{O}_{2}$, glucose, and ATP deprivation following SD augments ischemic conditions and exacerbates cell damage and death in CVDs $[28,157,158]$. SD clusters with prolonged depression phases promote delayed ischemic brain damage after SAH and malignant ischemic stroke $[35,159]$, possibly via reduction of $\mathrm{O}_{2}$ supply and enhancement of $\mathrm{O}_{2}$ consumption [160]. In experimental models of brain ischemia, the occurrence of SD in the ischemic penumbra and outside of the penumbra zone leads to cell damage and death as well as enlargement of the ischemic core and the infarct zone [161-163]. Clinical investigations reveal a strong association between repetition rate of spontaneous SD and delayed ischemic neurological deficits [35]. In addition to the mismatch between supply and demand [164], lowering the seizure threshold [148, 165], disruption of the BBB [166], and SD-induced inflammatory responses contributes to tissue damage and clinical outcomes of patients with CVDs [167]. SD can affect both ischemic preconditioning and ischemic-induced brain injury after CVDs [107, 114].

These diverse effects on ischemic preconditioning and ischemic-induced brain injury could be dependent on the vicinity of the damaged cerebral area. SD is the mechanism of the cytotoxic edema [31]. The SD-induced cytotoxic edema occurs very early after the onset of ischemia, which is clearly not beneficial to the brain. However, in healthy tissue surrounding the ischemic zone, SD could have beneficial effects via upregulation of growth factors, stress response proteins, and potentially beneficial inflammatory mediators $[168,169]$. This may enhance synaptic plasticity [170], boost regeneration process [171, 172], and reduce the vascular steal effect on ischemic zones through the physiological oligemia [173]. Furthermore, it seems that TLR signaling pathway may exert controversial effects in early stages of various CVDs.TLR-4 in AIS exerts neuroprotective effect via ischemic preconditioning, while it is detrimental in $\mathrm{ICH}$. The beneficial effect of SD on these pathological conditions could be dependent on the extent of ischemic injury in the implicated neuronal tissues [172].

Several investigations indicate that both SD and CVDs are potent modulators of immediate early genes (such as c-JUN, JUN B, JUN D, c-Fos, Fos B, and KROX-24) [174-176]. Within the same time course of immediate early gene, SD and CVDs induce heat shock proteins $[177,178]$. Furthermore, upregulation of neurotrophic mediators is associated within early phases of SD and CVDs [169]. These early alterations may contribute to the preconditioning phenomenon in CVDs. The activation of immediate early genes and heat shock proteins as well as upregulation of neurotrophic cascade may exert neuroprotective effects and prevent post-ischemic inflammation and neuronal injury $[179,180]$. However, delayed SD-induced inflammatory cascades seem to be harmful for neuronal tissues. 
Using animal models for SD and brain ischemia, it has been shown that an increased prostaglandin and subsequently COX-2 production was observed within hours after SD and brain ischemia in perifocal neocortex, the hippocampus, and the striatum as well as in endothelial cells in the infarct core, which may amplify the ischemic inflammation and cell death via enhancement of edema and delivery of pro-inflammatory cells into the ischemic brain [181]. However, the role of COX-2 in SD-induced inflammatory responses could be a more complex issue. Although COX-2 is upregulated by $\mathrm{SD}$, the selective inhibition of COX-2 has proven to be ineffective at altering the $\mathrm{DC}$ signature or the $\mathrm{rCBF}$ response to $\mathrm{SD}$, at least within the first hours after SD induction or ischemia onset [182]. SD-induced hyperexcitability activates microglia and astrocytes and promotes the release of pro-inflammatory mediators, such as TNF $\alpha$, reactive oxygen species (ROS), and interferon [183-185], which may lead to neuronal tissue damage. Oxidative stress that leads in the enhancement of ROS can damage DNA and potentiate neuronal injury and death following $\mathrm{H}-\mathrm{I}$ injury [186]. SD in intact rodent brain results in microglia activation and a strong induction of the proinflammatory cytokines TNF- $\alpha$ and IL-1 $\beta$ [187]. Furthermore, the expressions of IL- $1 \alpha$, IL-2, IL-4, IL-6, IL-10, IFN- $\gamma$, and TNF- $\alpha$ proteins markedly enhanced after SD with localization of IL- $1 \alpha$ and IFN- $\gamma$ to microglia in hippocampal organotypic cultures [168]. Increased potassium concentration during SD augments the production of glial inflammatory factors nitric oxide and TNF- $\alpha$, which exert toxic effects on neuronal tissues [188]. Furthermore, SD-induced inflammatory response is associated with the activation of macrophages and mast cells and a rise in cytokine levels [189, 190].

Numerous amounts of evidence suggest that SDinduced inflammatory responses contribute to cell damage and death in both in hypoxic and intact conditions. SD upregulates a set of inflammation-related genes [183], many of those, like $x$-box binding protein-1 and interferon regulatory factor-1, contribute to cell injury and apoptosis in patients with CVDs [180, 191, 192]. SD-related caspase activation, as a part of inflammatory response to neuronal stresses [193], is associated with a widespread apoptosis and cell damage in the neocortex and hippocampus [44]. SD-induced cell damage and apoptosis are correlated with the activation of synaptic plasticity and higher expression levels of glutamatergic NMDA and AMPA receptors [46]. Activation of caspase cascade could be due to SD-induced release of different cytokines, such as IFN- $\gamma$ and TNF- $\alpha[168,194]$.

Accumulating evidence points to the role of TLRs in SD-induced cell damage and apoptosis in neuronal tissues. Experimental studies revealed that SD induces a marked release of HMGB1, an important ligand of TLR2 and TLR4 [195]. Repetitive SD leads to the activation of microglia associated with an increased transcription activity of the HMGB1 receptor genes, TLR2 and TLR4. Furthermore, an enhanced expression of the lysosomal acid hydrolase cathepsin D accompanied by microglial hypertrophy has been reported after repetitive SD, indicating a higher microglia lysosomal phagocytic activity following SD [53]. In addition to microglia, astrocytes may play a role in TLR-related inflammatory conditions after SD. Induction of reactive astrocytosis has been reported in different CVDs [196] as well as after SD [197], which may potentiate neuroinflammation through the production of inflammatory mediators, such as ROS, chemokines, and cytokines [198]. SD significantly increases the expression of TLR4 and TLR3 in addition to TNF- $\alpha$, IL- 6 , and IL- $1 \beta$ in rat somatosensory cortices. In addition, the expressions of TLR4 and TLR3 as well as various pro-inflammatory cytokines markedly increase in cultured astrocytes obtained from SD-treated rat brain [49]. SD leads to parenchymal inflammatory response via neuronal Pannexin1 megachannel opening as well as caspase- 1 activation followed by HMGB1 release from neurons and nuclear factor $\mathrm{kB}$ activation in astrocytes [193]. Administration of TLR ligands at low concentration prior to $\mathrm{H}-\mathrm{I}$ insults induces neuroprotection, pointing to the crucial role of these receptors in preconditioning [20]. Application of Poly I:C, a synthetic analogue of dsRNA and TLR3 agonist, reduces cerebral injury through TLR3-mediated prevention of H-Iinduced activation of Fas/FADD-mediated apoptotic signaling and microglia caspase- 3 and -8 activities [199] as well as the downregulation of TLR4 signaling via TLR3 [200] in animal models of cerebral ischemia. Interestingly, prophylactic application of Poly I:C significantly prevents the production of SD-induced cell injury and attenuates the induction of TNF- $\alpha$, IFN- $\gamma$, and Hsp70 in the brain as well as TNF- $\alpha$ and IL-4 in the spleen. Furthermore, Poly I:C modulates GABAergic neurotransmission, which may inhibit SD-induced neuronal hyperexcitability [201].

\section{Conclusion}

Enormous amounts of experimental and clinical data indicate that SD can modulate neural tissue injury and clinical outcomes in different CVDs. SD contributes to both ischemic preconditioning and exacerbation of cerebral injury and outcome after CVDs. A part of the SD effect on pathological process of CVDs could be due to SD-induced inflammatory responses. TLRs are common signaling pathways in SD- and CVD-induced neuroinflammation. Considering the double-edged role of TLRrelated inflammatory responses in both CVDs and SDbeneficial in the acute phase and destructive in the late 
phase-targeting these receptors may provide novel therapeutic approaches for CVDs and other SD-related disorders. Furthermore, manipulation of TLRs may exert a modulatory effect on SD occurrence and regulate the following pathological conditions.

\section{Abbreviations}

AIS: Acute ischemic stroke; BBB: Blood-brain barrier; COX-2: Cyclooxygenase2; CpG-OdN: Cytosine-guanine oligodeoxynucleotides; CVDs: Cerebrovascular diseases; CVST: Cerebral venous sinus thrombosis; DAMPs: Disease-associated molecular patterns; DC: Dendritic cell; dsDNA: Double-stranded DNA; dsRNA: Double-stranded RNA; H-l: Hypoxic-ischemic; HMGB1: High mobility group box 1; ICH: Intracerebral hemorrhage; IFN: Interferon; IL-6: Interleukin-6; IRF: Interferon regulatory factor; LPS: Lipopolysaccharide; MyD88: Myeloid differentiation primary response 88; NFkB: Nuclear factor-kB; PAMPs: Pathogen-associated molecular patterns; PPAR- $\gamma$ : Peroxisome proliferator-activated receptor gamma; rCBF: Regional cerebral blood flow; SAH: Subarachnoid hemorrhage; SD: Spreading depolarization; ssRNA: Singlestranded RNA; TAK-242: Ethyl(6R)-6-[N-(2-chloro-4-fluorophenyl) sulfamoyl] cyclohex-1-ene-1-carboxylate; TIR: Toll/IL1 receptor; TLRs: Toll-like receptors; TRIF: TIR-domain-containing adapter-inducing interferon- $\beta$

\section{Acknowledgements}

Not applicable.

\section{Authors' contributions}

RAA carried out the literature review and drafted the manuscript. MKG helped to draft the manuscript. AG conceived, designed and coordinated the study, and contributed to and finalized the draft. All authors read and approved the final manuscript.

\section{Funding}

The authors received no financial support for the research, authorship, and/ or publication of this article.

\section{Availability of data and materials}

Authors confirm that all relevant data are included in the article.

\section{Ethics approval and consent to participate}

Not applicable.

\section{Consent for publication}

Not applicable as no patients/participants involved in this review.

\section{Competing interests}

The authors declare that they have no competing interests.

\section{Author details}

'Shefa Neuroscience Research Center, Khatam Alanbia Hospital, Tehran, Iran. ${ }^{2}$ Department of Neurosurgery, Westfälische Wilhelms-Universität Münster, Münster, Germany. ${ }^{3}$ Epilepsy Research Center, Westfälische Wilhelms-Universität Münster, Münster, Germany. ${ }^{4}$ Department of Neurology, Westfälische Wilhelms-Universität Münster, Münster, Germany. ${ }^{5}$ Neuroscience research Center, Mashhad University of Medical Sciences, Mashhad, Iran.

Received: 10 January 2020 Accepted: 24 March 2020

Published online: 07 April 2020

\section{References}

1. Rajendran P, Rengarajan T, Thangavel J, Nishigaki Y, Sakthisekaran D, Sethi $\mathrm{G}$, et al. The vascular endothelium and human diseases. Int J Biol Sci. 2013;9: 1057.

2. Tsze DS, Valente JH. Pediatric stroke: a review. Emergency Medicine International. 2011:2011:734506.

3. Lopez AD, Mathers CD, Ezzati M, Jamison DT, Murray CJ. Global and regional burden of disease and risk factors, 2001: systematic analysis of population health data. Lancet. 2006;367:1747-57.

4. Murray CJ, Vos T, Lozano R, Naghavi M, Flaxman AD, Michaud C, et al. Disability-adjusted life years (dalys) for 291 diseases and injuries in 21 regions, 1990-2010: a systematic analysis for the global burden of disease study 2010. Lancet. 2012;380:2197-223.

5. Hartmann G, Tschöp M, Fischer R, Bidlingmaier C, Riepl R, Tschöp K, et al. High altitude increases circulating interleukin-6, interleukin-1 receptor antagonist and c-reactive protein. Cytokine. 2000;12:246-52.

6. Krüger B, Krick S, Dhillon N, Lerner SM, Ames S, Bromberg JS, et al. Donor toll-like receptor 4 contributes to ischemia and reperfusion injury following human kidney transplantation. Proc Natl Acad Sci U S A. 2009;106:3390-5.

7. Kaelin WG Jr, Ratcliffe PJ. Oxygen sensing by metazoans: the central role of the hif hydroxylase pathway. Mol Cell. 2008;30:393-402.

8. Ferdinand $\mathrm{P}$, Roffe C. Hypoxia after stroke: a review of experimental and clinical evidence. Experimental \& translational stroke medicine. 2016;8:9.

9. Giatromanolaki A, Sivridis E, Maltezos E, Papazoglou D, Simopoulos C, Gatter $\mathrm{K}$, et al. Hypoxia inducible factor $1 \mathrm{a}$ and $2 \mathrm{a}$ overexpression in inflammatory bowel disease. 2003:56:209-213.

10. Downes CE, Crack PJ. Neural injury following stroke: are toll-like receptors the link between the immune system and the cns? Br J Pharmacol. 2010;160:1872-88.

11. Taylor CT. Interdependent roles for hypoxia inducible factor and nuclear factor-kb in hypoxic inflammation. J Physiol. 2008:586:4055-9.

12. Liu T, Zhang L, Joo D, Sun S-C. Nf-kb signaling in inflammation. Signal Transduction and Targeted Therapy. 2017:2:17023.

13. Medzhitov R. Toll-like receptors and innate immunity. Nat Rev Immunol. 2001:1:135.

14. Li M, Liu J, Bi Y, Chen J, Zhao L. Potential medications or compounds acting on toll-like receptors in cerebral ischemia. Curr Neuropharmacol. 2018;16: 160-75.

15. García-Culebras A, Durán-Laforet V, Peña-Martínez C, Moraga A, Ballesteros I, Cuartero $\mathrm{Ml}$, et al. Role of tlr4 (toll-like receptor 4 ) in $\mathrm{n} 1 / \mathrm{n} 2$ neutrophil programming after stroke. Stroke. 2019;50:2922-32.

16. Tajalli-Nezhad S, Karimian M, Beyer C, Atlasi MA, Tameh AA. The regulatory role of toll-like receptors after ischemic stroke: neurosteroids as tlr modulators with the focus on tIr2/4. Cell Mol Life Sci. 2019:76:523-37.

17. Hayward JH, Lee SJ. A decade of research on tlr2 discovering its pivotal role in glial activation and neuroinflammation in neurodegenerative diseases. Experimental neurobiology. 2014;23:138-47.

18. Zhou Y, Wang Y, Wang J, Stetler RA, Yang Q-W. Inflammation in intracerebral hemorrhage: from mechanisms to clinical translation. Prog Neurobiol. 2014;115:25-44.

19. Suzuki H, Fujimoto M, Kawakita F, Liu L, Nakatsuka Y, Nakano F, et al. Tenascin-c in brain injuries and edema after subarachnoid hemorrhage: findings from basic and clinical studies. J Neurosci Res. 2018.

20. Gesuete R, Kohama SG, Stenzel-Poore MP. Toll-like receptors and ischemic brain injury. J Neuropathol Exp Neurol. 2014;73:378-86.

21. Wang $P-F$, Xiong $X-Y$, Chen J, Wang $Y-C$, Duan W, Yang Q-W. Function and mechanism of toll-like receptors in cerebral ischemic tolerance: from preconditioning to treatment. J Neuroinflammation. 2015;12:80,

22. Buchanan MM, Hutchinson M, Watkins LR, Yin H. Toll-like receptor 4 in cns pathologies. J Neurochem. 2010;114:13-27.

23. Macrez R, Ali C, Toutirais O, Le Mauff B, Defer G, Dirnagl U, et al. Stroke and the immune system: from pathophysiology to new therapeutic strategies. The Lancet Neurology. 2011;10:471-80.

24. Brien JD, Daffis S, Lazear HM, Cho H, Suthar MS, Gale M Jr, et al. Interferon regulatory factor-1 (irf-1) shapes both innate and cd8+t cell immune responses against west nile virus infection. PLoS Pathog. 2011;7.

25. Wang $Y-C$, Wang P-F, Fang $H$, Chen J, Xiong $X-Y$, Yang Q-W. Toll-like receptor 4 antagonist attenuates intracerebral hemorrhage-induced brain injury. Stroke. 2013:44:2545-52.

26. Kovac S, Speckmann E-J, Gorji A. Uncensored eeg: the role of dc potentials in neurobiology of the brain. Prog Neurobiol. 2018;165:51-65.

27. Nicholson C, Kraig R. The behavior of extracellular ions during spreading depression. The application of ion-selective microelectrodes. 1981:217-38.

28. Somjen G, Aitken P, Balestrino M, Herreras O, Kawasaki K. Spreading depression-like depolarization and selective vulnerability of neurons. A brief review. Stroke. 1990:21:111179-83.

29. Ayata C, Lauritzen M. Spreading depression, spreading depolarizations, and the cerebral vasculature. Physiol Rev. 2015;95:953-93.

30. Hoffmann U, Ayata C. Neurovascular coupling during spreading depolarizations. Cerebral vasospasm: Neurovascular events after subarachnoid hemorrhage. Springer; 2013:161-165.

31. Dreier JP, Lemale CL, Kola V, Friedman A, Schoknecht K. Spreading depolarization is not an epiphenomenon but the principal mechanism of 
the cytotoxic edema in various gray matter structures of the brain during stroke. Neuropharmacology. 2018;134:189-207.

32. Dreier JP, Major S, Foreman B, Winkler MK, Kang EJ, Milakara D, et al. Terminal spreading depolarization and electrical silence in death of human cerebral cortex. Ann Neurol. 2018;83:295-310.

33. Carlson AP, Shuttleworth CW, Major S, Lemale CL, Dreier JP, Hartings JA. Terminal spreading depolarizations causing electrocortical silencing prior to clinical brain death: case report. J Neurosurg. 2018;131:1773-9.

34. Dohmen C, Sakowitz OW, Fabricius M, Bosche B, Reithmeier T, Ernestus Rl, et al. Spreading depolarizations occur in human ischemic stroke with high incidence. Annals of Neurology: Official Journal of the American Neurological Association and the Child Neurology Society. 2008;63:720-8.

35. Dreier JP, Woitzik J, Fabricius M, Bhatia R, Major S, Drenckhahn C, et al. Delayed ischaemic neurological deficits after subarachnoid haemorrhage are associated with clusters of spreading depolarizations. Brain. 2006;129:3224-37.

36. Fabricius M, Fuhr S, Bhatia R, Boutelle M, Hashemi P, Strong AJ, et al. Cortical spreading depression and peri-infarct depolarization in acutely injured human cerebral cortex. Brain. 2005;129:778-90.

37. Strong AJ, Macdonald RL. Cortical spreading ischemia in the absence of proximal vasospasm after aneurysmal subarachnoid hemorrhage: evidence for a dual mechanism of delayed cerebral ischemia. J Cereb Blood Flow Metab. 2012;32:201-2.

38. Lückl J, Lemale CL, Kola V, Horst V, Khojasteh U, Oliveira-Ferreira Al, et al. The negative ultraslow potential, electrophysiological correlate of infarction in the human cortex. Brain. 2018;141:1734-52.

39. Hartings JA, Shuttleworth CW, Kirov SA, Ayata C, Hinzman JM, Foreman B, et al. The continuum of spreading depolarizations in acute cortical lesion development: examining leão's legacy. J Cereb Blood Flow Metab. 2017;37: 1571-94.

40. Marrannes R, Willems R, De Prins E, Wauquier A. Evidence for a role of the $\mathrm{n}$-methyl-d-aspartate ( $\mathrm{nmda}$ ) receptor in cortical spreading depression in the rat. Brain Res. 1988:457:226-40.

41. Lauritzen M, Hansen AJ. The effect of glutamate receptor blockade on anoxic depolarization and cortical spreading depression. J Cereb Blood Flow Metab. 1992;12:223-9.

42. Shibata M, Suzuki N. Exploring the role of microglia in cortical spreading depression in neurological disease. J Cereb Blood Flow Metab. 2017;37: 1182-91.

43. Dreier JP, Fabricius M, Ayata C, Sakowitz OW, William Shuttleworth C, Dohmen C, et al. Recording, analysis, and interpretation of spreading depolarizations in neurointensive care: review and recommendations of the cosbid research group. J Cereb Blood Flow Metab. 2017;37:1595-625.

44. Jahan-Abad AJ, Alizadeh L, Negah SS, Barati P, Ghadiri MK, Meuth SG, et al. Apoptosis following cortical spreading depression in juvenile rats. Mol Neurobiol. 2018;55:4225-39.

45. Lauritzen M, Dreier JP, Fabricius M, Hartings JA, Graf R, Strong AJ. Clinical relevance of cortical spreading depression in neurological disorders: migraine, malignant stroke, subarachnoid and intracranial hemorrhage, and traumatic brain injury. J Cereb Blood Flow Metab. 2011;31:17-35.

46. Sadeghian H, Jafarian M, Karimzadeh F, Kafami L, Kazemi H, Coulon P, et al. Neuronal death by repetitive cortical spreading depression in juvenile rat brain. Exp Neurol. 2012;233:438-46.

47. Dreier JP, Körner K, Ebert N, Görner A, Rubin I, Back T, et al. Nitric oxide scavenging by hemoglobin or nitric oxide synthase inhibition by $n$-nitro-larginine induces cortical spreading ischemia when $\mathrm{k}+$ is increased in the subarachnoid space. J Cereb Blood Flow Metab. 1998;18:978-90.

48. Dreier JP, Major S, Manning A, Woitzik J, Drenckhahn C, Steinbrink J, et al. Cortical spreading ischaemia is a novel process involved in ischaemic damage in patients with aneurysmal subarachnoid haemorrhage. Brain. 2009;132:1866-81.

49. Ghaemi A, Alizadeh L, Babaei S, Jafarian M, Khaleghi Ghadiri M, Meuth SG, et al. Astrocyte-mediated inflammation in cortical spreading depression. Cephalalgia. 2018;38:626-38.

50. Jafarian M, Rahimi S, Behnam F, Hosseini M, Haghir H, Sadeghzadeh B, et al. The effect of repetitive spreading depression on neuronal damage in juvenile rat brain. Neuroscience. 2010;169:388-94.

51. Pomper JK, Haack S, Petzold GC, Buchheim K, Gabriel S, Hoffmann U, et al. Repetitive spreading depression-like events result in cell damage in juvenile hippocampal slice cultures maintained in normoxia. J Neurophysiol. 2006;95 355-68.
52. Nedergaard M, Hansen AJ. Spreading depression is not associated with neuronal injury in the normal brain. Brain Res. 1988;449:395-8.

53. Takizawa T, Shibata M, Kayama Y, Shimizu T, Toriumi H, Ebine T, et al. Highmobility group box 1 is an important mediator of microglial activation induced by cortical spreading depression. J Cereb Blood Flow Metab. 2017; 37:890-901.

54. Glezer I, Simard A, Rivest S. Neuroprotective role of the innate immune system by microglia. Neuroscience. 2007;147:867-83.

55. McGettrick AF, O'Neill LA. Toll-like receptors: key activators of leucocytes and regulator of haematopoiesis. Br J Haematol. 2007;139:185-93.

56. Wu Y-d, Zhou BJ. Tnf-a/nf-kb/snail pathway in cancer cell migration and invasion. Br J Cancer. 2010;102:639-44.

57. Arancibia SA, Beltrán CJ, Aguirre IM, Silva P, Peralta AL, Malinarich F, et al. Toll-like receptors are key participants in innate immune responses. Biol Res. 2007:40:97-112

58. Xu S, Tian R, Lin Y, Yu Z, Zhang Z, Niu X, et al. Widespread positive selection on cetacean tlr extracellular domain. Mol Immunol. 2019;106:135-42.

59. Kawasaki T, Kawai T. Toll-like receptor signaling pathways. Front Immunol. 2014;5:461.

60. Okun E, Griffioen KJ, Mattson MP. Toll-like receptor signaling in neural plasticity and disease. Trends Neurosci. 2011;34:269-81.

61. Mahla RS, Reddy CM, Prasad D, Kumar HJ. Sweeten pamps: role of sugar complexed pamps in innate immunity and vaccine biology. Front Immunol. 2013:4:248.

62. Honda K, Ohba Y, Yanai H, Negishi H, Mizutani T, Takaoka A, et al. Spatiotemporal regulation of myd88-irf-7 signalling for robust type-i interferon induction. Nature. 2005;434:1035-40.

63. Kawai T, Akira SJ. The role of pattern-recognition receptors in innate immunity: Update on toll-like receptors. Nat Immunol. 2010;11:373.

64. Takahashi H, Nishibori MJ. Current status and future prospects in hmgb1 and receptor researches. Nihon Rinsho. 2016;74:703-11.

65. Hayakawa K, Qiu J, Lo EH. Biphasic actions of hmgb1 signaling in inflammation and recovery after stroke. Ann N Y Acad Sci. 2010;1207:50

66. Hossain MJ, Tanasescu R, Gran BJ. Innate immune regulation of autoimmunity in multiple sclerosis: Focus on the role of toll-like receptor 2. J Neuroimmunol. 2017;304:11-20.

67. van Vliet EA, Aronica E, Vezzani A, Ravizza T. Neuroinflammatory pathways as treatment targets and biomarker candidates in epilepsy: emerging evidence from preclinical and clinical studies. Neuropathol Appl Neurobiol. 2018:44:91-111.

68. Bisht K, Sharma K, Tremblay M-È. Chronic stress as a risk factor for alzheimer's disease: roles of microglia-mediated synaptic remodeling, inflammation, and oxidative stress. Neurobiol Stress. 2018:9:9-21.

69. Frederiksen HR, Haukedal H, Freude KJ. Cell type specific expression of tolllike receptors in human brains and implications in alzheimer's disease. 2019; 2019

70. Ellrichmann G, Reick C, Saft C, Linker RAJC, Immunology D. The role of the immune system in huntington's disease. 2013;2013.

71. Mosley RL, Hutter-Saunders JA, Stone DK, Gendelman HE. Inflammation and adaptive immunity in parkinson's disease. Cold Spring Harb Perspect Med. 2012;2:a009381.

72. Maetzler W, Berg D, Synofzik M, Brockmann K, Godau J, Melms A, et al. Autoantibodies against amyloid and glial-derived antigens are increased in serum and cerebrospinal fluid of lewy body-associated dementias. J Alzheimers Dis. 2011;26:171-9.

73. Puentes F, Topping J, Kuhle J, van der Star BJ, Douiri A, Giovannoni G, et al. Immune reactivity to neurofilament proteins in the clinical staging of amyotrophic lateral sclerosis. J Neurol Neurosurg Psychiatry. 2014;85:274-8.

74. Sta M, Sylva-Steenland R, Casula M, de Jong J, Troost D, Aronica E, et al. Innate and adaptive immunity in amyotrophic lateral sclerosis: evidence of complement activation. Neurobiol Dis. 2011;42:211-20.

75. Ramachandran R, Wang Z, Saavedra C, DiNardo A, Corr M, Powell SB, et al. Role of toll-like receptor 4 signaling in mast cell-mediated migraine pain pathway. 2019;15:1744806919867842.

76. Kumar VJ. Toll-like receptors in the pathogenesis of neuroinflammation. 2019

77. Shi H, Hua X, Kong D, Stein D, Hua FJ. Role of toll-like receptor mediated signaling in traumatic brain injury. Neuropharmacology. 2019;145:259-67.

78. Arslan F, Keogh B, McGuirk P, Parker A. Tlr2 and tlr4 in ischemia reperfusion injury. Mediators of inflammation. 2010;2010.

79. Wang Y, Ge P, Zhu Y. TIr2 and tlr4 in the brain injury caused by cerebral ischemia and reperfusion. Mediators of inflammation. 2013;2013. 
80. Lopez-Pedrera C, Barbarroja N, Collantes E, Aguirre M, Perez-Sanchez C. New biomarkers for atherothrombosis in antiphospholipid syndrome: genomics and epigenetic approaches. Front Immunol. 2019;10:764.

81. Packard AE, Hedges JC, Bahjat FR, Stevens SL, Conlin MJ, Salazar AM, et al. Poly-ic preconditioning protects against cerebral and renal ischemiareperfusion injury. J Cereb Blood Flow Metab. 2012;32:242-7.

82. Lin S, Yin Q, Zhong Q, Lv F-L, Zhou Y, Li J-Q, et al. Heme activates tir4mediated inflammatory injury via myd88/trif signaling pathway in intracerebral hemorrhage. J Neuroinflammation. 2012;9:46.

83. Hanafy KA. The role of microglia and the tlr4 pathway in neuronal apoptosis and vasospasm after subarachnoid hemorrhage. J Neuroinflammation. 2013;10:868.

84. Leung PY, Stevens SL, Packard AE, Lessov NS, Yang T, Conrad VK, et al. Toll-like receptor 7 preconditioning induces robust neuroprotection against stroke by a novel type i interferon-mediated mechanism. Stroke. 2012;43:1383-9.

85. Brea D, Sobrino T, Rodríguez-Yáñez M, Ramos-Cabrer P, Agulla J, RodríguezGonzález R, et al. Toll-like receptors 7 and 8 expression is associated with poor outcome and greater inflammatory response in acute ischemic stroke. Clin Immunol. 2011;139:193-8.

86. Libby $P$, Okamoto $Y$, Rocha VZ, Folco E. Inflammation in atherosclerosis: transition from theory to practice. Circ J. 2010;74:213-20.

87. Ziegler G, Freyer D, Harhausen D, Khojasteh U, Nietfeld W, Trendelenburg $\mathrm{GJ}$, et al. Blocking tlr2 in vivo protects against accumulation of inflammatory cells and neuronal injury in experimental stroke. J Cereb Blood Flow Metab. 2011;31:757-66

88. Li H, Sun BJ. Toll-like receptor 4 in atherosclerosis. J Cell Mol Med. 2007;11: 88-95.

89. Pasterkamp G, Van Keulen J, De Kleijn DJ. Role of toll-like receptor 4 in the initiation and progression of atherosclerotic disease. Eur J Clin Investig. 2004;34:328-34.

90. Bobryshev $\mathrm{V}$, Ikezawa T, Watanabe TJA. Formation of birbeck granule-like structures in vascular dendritic cells in human atherosclerotic aorta: lagantibody to epidermal langerhans cells recognizes cells in the aortic wall. Atherosclerosis. 1997;133:193-202

91. Edfeldt K, Swedenborg J, Hansson GK, Yan Z-q. Expression of toll-like receptors in human atherosclerotic lesions: a possible pathway for plaque activation. Circulation. 2002;105:1158-61.

92. Hoshino K, Kaisho T, Iwabe T, Takeuchi O, Akira SJ. Differential involvement of ifn- $\beta$ in toll-like receptor-stimulated dendritic cell activation. Int Immunol. 2002;14:1225-31.

93. Vink A, Schoneveld AH, van der Meer JJ, van Middelaar BJ, Sluijter JP, Smeets MB, et al. In vivo evidence for a role of toll-like receptor 4 in the development of intimal lesions. Circulation. 2002;106:1985-90.

94. Okamura Y, Watari M, Jerud ES, Young DW, Ishizaka ST, Rose J, et al. The extra domain a of fibronectin activates toll-like receptor 4. J Biol Chem. 2001;276:10229-33.

95. Larochelle A, Bellavance M-A, Rivest S. Role of adaptor protein myd88 in tlrmediated preconditioning and neuroprotection after acute excitotoxicity. Brain Behav Immun. 2015:46:221-31.

96. Tasaki K, Ruetzler CA, Ohtsuki T, Martin D, Nawashiro H, Hallenbeck JM. Lipopolysaccharide pre-treatment induces resistance against subsequent focal cerebral ischemic damage in spontaneously hypertensive rats. Brain Res. 1997;748:267-70.

97. Doyle KP, Simon RP, Stenzel-Poore MP. Mechanisms of ischemic brain damage. Neuropharmacology. 2008:55:310-8.

98. Marsh B, Stevens SL, Packard AE, Gopalan B, Hunter B, Leung PY, et al. Systemic lipopolysaccharide protects the brain from ischemic injury by reprogramming the response of the brain to stroke: a critical role for irf3. J Neurosci. 2009;29:9839-49.

99. Rosenzweig HL, Minami M, Lessov NS, Coste SC, Stevens SL, Henshall DC, et al. Endotoxin preconditioning protects against the cytotoxic effects of tnfa after stroke: a novel role for tnfa in Ips-ischemic tolerance. J Cereb Blood Flow Metab. 2007;27:1663-74.

100. Bahjat FR, West GA, Kohama SG, Glynn C, Urbanski HF, Hobbs TR, et al. Preclinical development of a prophylactic neuroprotective therapy for the preventive treatment of anticipated ischemia-reperfusion injury. Transl Stroke Res. 2017;8:322-33.

101. Bahjat FR, Williams-Karnesky RL, Kohama SG, West GA, Doyle KP, Spector $M D$, et al. Proof of concept: pharmacological preconditioning with a toll-like receptor agonist protects against cerebrovascular injury in a primate model of stroke. J Cereb Blood Flow Metab. 2011;31:1229-42.
102. Marsh BJ, Stevens SL, Hunter B, Stenzel-Poore MP. Inflammation and the emerging role of the toll-like receptor system in acute brain ischemia. Stroke. 2009;40:534-7.

103. Lu C, Ha T, Wang X, Liu L, Zhang X, Kimbrough EO, et al. The tlr 9 ligand, cpg-odn, induces protection against cerebral ischemia/reperfusion injury via activation of pi3k/akt signaling. J Am Heart Assoc. 2014;3:e000629.

104. Hua F, Ma J, Ha T, Kelley JL, Kao RL, Schweitzer JB, et al. Differential roles of tlr2 and tir4 in acute focal cerebral ischemia/reperfusion injury in mice. Brain Res. 2009;1262:100-8.

105. Wang Y, Ge P, Zhu Y. Tlr2 and tlr4 in the brain injury caused by cerebral ischemia and reperfusion. Mediat Inflamm. 2013;2013:124614.

106. García-Culebras A, Palma-Tortosa S, Moraga A, García-Yébenes I, DuránLaforet V, Cuartero Ml, et al. Toll-like receptor 4 mediates hemorrhagic transformation after delayed tissue plasminogen activator administration in in situ thromboembolic stroke. Stroke. 2017:48:1695-9.

107. Pradillo JM, Fernández-López D, García-Yébenes I, Sobrado M, Hurtado O, Moro MA, et al. Toll-like receptor 4 is involved in neuroprotection afforded by ischemic preconditioning. J Neurochem. 2009;109:287-94.

108. Kramer B, França LM, Zhang Y, de Andrade Paes AM, Gerdes AM, CarrilloSepulveda MA. Western diet triggers toll-like receptor 4 signaling-induced endothelial dysfunction in female wistar rats. Am J Phys Heart Circ Phys. 2018;315:H1735-47.

109. Singh V, Roth S, Veltkamp R, Liesz A. Hmgb1 as a key mediator of immune mechanisms in ischemic stroke. Antioxid Redox Signal. 2016;24:635-51.

110. Ye $Y$, Zeng $Z$, Jin $T$, Zhang $H$, Xiong $X, G u L$. The role of high mobility group box 1 in ischemic stroke. Front Cell Neurosci. 2019;13:127.

111. Goldstein RS, Gallowitsch-Puerta M, Yang L, Rosas-Ballina M, Huston JM, Czura CJ, et al. Elevated high-mobility group box 1 levels in patients with cerebral and myocardial ischemia. Shock. 2006;25:571-4.

112. Richard SA, Sackey M, Su Z, Xu H. Pivotal neuroinflammatory and therapeutic role of high mobility group box 1 in ischemic stroke. 2017;37.

113. Tsukagawa T, Katsumata R, Fujita M, Yasui K, Akhoon C, Ono K, et al. Elevated serum high-mobility group box-1 protein level is associated with poor functional outcome in ischemic stroke. J Stroke Cerebrovasc Dis. 2017; 26:2404-11.

114. Stevens SL, Ciesielski TM, Marsh BJ, Yang T, Homen DS, Boule J-L, et al. Tolllike receptor 9: a new target of ischemic preconditioning in the brain. J Cereb Blood Flow Metab. 2008;28:1040-7.

115. Fang H, Wang P-F, Zhou Y, Wang Y-C, Yang Q-W. Toll-like receptor 4 signaling in intracerebral hemorrhage-induced inflammation and injury. J Neuroinflammation. 2013;10:794.

116. Rodríguez-Yáñez M, Brea D, Arias S, Blanco M, Pumar JM, Castillo J, et al. Increased expression of toll-like receptors 2 and 4 is associated with poor outcome in intracerebral hemorrhage. J Neuroimmunol. 2012;247:75-80.

117. Garton T, Keep RF, Hua Y, Xi G. Brain iron overload following intracranial haemorrhage. Stroke Vasc Neurol. 2016;1:172-84.

118. Dutra FF, Bozza M. Heme on innate immunity and inflammation. Front Pharmacol. 2014;5:115.

119. Wang YC, Zhou Y, Fang H, Lin S, Wang PF, Xiong RP, et al. Toll-like receptor 2/4 heterodimer mediates inflammatory injury in intracerebral hemorrhage. Ann Neurol. 2014:75:876-89.

120. Wang J, Doré S. Heme oxygenase-1 exacerbates early brain injury after intracerebral haemorrhage. Brain. 2007;130:1643-52.

121. Xiong X-Y, Liu L, Wang F-X, Yang Y-R, Hao J-W, Wang P-F, et al. Toll-like receptor $4 /$ myd88-mediated signaling of hepcidin expression causing brain iron accumulation, oxidative injury, and cognitive impairment after intracerebral hemorrhage. Circulation. 2016;134:1025-38.

122. Zhong Q, Zhou K, Liang QL, Lin S, Wang YC, Xiong XY, et al. Interleukin-23 secreted by activated macrophages drives $\gamma \delta$ t cell production of interleukin17 to aggravate secondary injury after intracerebral hemorrhage. J Am Heart Assoc. 2016;5:e004340

123. Garton T, Hua Y, Xiang J, Xi G, Keep RF. Challenges for intraventricular hemorrhage research and emerging therapeutic targets. Expert Opin Ther Targets. 2017;21:1111-22.

124. Aouar B, Kovarova D, Letard S, Font-Haro A, Florentin J, Weber J, et al. Dual role of the tyrosine kinase syk in regulation of toll-like receptor signaling in plasmacytoid dendritic cells. PLoS One. 2016;11:e0156063.

125. de Rivero Vaccari JC, Brand FJ III, Berti AF, Alonso OF, Bullock MR, de Rivero Vaccari JP. Mincle signaling in the innate immune response after traumatic brain injury. J Neurotrauma. 2015;32:228-36. 
126. Suzuki Y, Nakano Y, Mishiro K, Takagi T, Tsuruma K, Nakamura M, et al. Involvement of mincle and syk in the changes to innate immunity after ischemic stroke. Sci Rep. 2013;3:3177.

127. Xu P, Zhang X, Liu Q, Xie Y, Shi X, Chen J, et al. Microglial trem-1 receptor mediates neuroinflammatory injury via interaction with syk in experimental ischemic stroke. Cell Death Dis. 2019;10:1-17.

128. Liu X-Y, Dai X-H, Zou W, Yu X-P, Teng W, Wang Y, et al. Acupuncture through baihui (du20) to qubin (gb7) mitigates neurological impairment after intracerebral hemorrhage. Neural Regen Res. 2018;13:1425.

129. D'Souza S. Aneurysmal subarachnoid hemorrhage. 2015;27:222.

130. Keyrouz SG, Diringer MN. Clinical review: prevention and therapy of vasospasm in subarachnoid hemorrhage. Crit Care. 2007;11:220.

131. W-n Y, B-w C, Jian W, Wang J-y, Min H, Hong S, et al. Toll-like receptor 4/ nuclear factor-kappa b signaling detected in brain after early subarachnoid hemorrhage. Chin Med J. 2009;122:1575-81.

132. Kurki MI, Häkkinen S-K, Frösen J, Tulamo R, von Und Zu Fraunberg M, Wong $\mathrm{G}$, et al. Upregulated signaling pathways in ruptured human saccular intracranial aneurysm wall: an emerging regulative role of toll-like receptor signaling and nuclear factor-kb, hypoxia-inducible factor-1a, and ets transcription factors. Neurosurgery. 2011;68:1667-76.

133. Zhou M-I, Wu W, Ding Y-s, Zhang F-f, Hang C-h, Wang H-d, et al. Expression of toll-like receptor 4 in the basilar artery after experimental subarachnoid hemorrhage in rabbits: a preliminary study. Brain Res. 2007;1173:110-6.

134. Aoki T, Nishimura M, Ishibashi R, Kataoka H, Takagi Y, Hashimoto N. Toll-like receptor 4 expression during cerebral aneurysm formation. J Neurosurg. 2010;113:851-8.

135. Nishimura M. Erratum: Toll-like receptor 4 expression during cerebral aneurysm formation. J Neurosurg. 2013;119:825-7.

136. Fujimoto M, Suzuki H, Shiba M, Shimojo N, Imanaka-Yoshida K, Yoshida T, et al. Tenascin-c induces prolonged constriction of cerebral arteries in rats. Neurobiol Dis. 2013;55:104-9.

137. Roquilly A, Braudeau C, Cinotti R, Dumonte E, Motreul R, Josien R, et al. Impaired blood dendritic cell numbers and functions after aneurysmal subarachnoid hemorrhage. PLoS One. 2013;8:e71639.

138. Lublinsky S, Major S, Kola V, Horst V, Santos E, Platz J, et al. Early blood-brain barrier dysfunction predicts neurological outcome following aneurysmal subarachnoid hemorrhage. EBioMedicine. 2019;43:460-72

139. Okada T, Kawakita F, Nishikawa H, Nakano F, Liu L, Suzuki H. Selective tolllike receptor 4 antagonists prevent acute blood-brain barrier disruption after subarachnoid hemorrhage in mice. Mol Neurobiol. 2019;56:976-85.

140. Wu Y, Zhao X-D, Zhuang Z, Xue Y-J, Cheng H-L, Yin H-X, et al. Peroxisome proliferator-activated receptor gamma agonist rosiglitazone attenuates oxyhemoglobin-induced toll-like receptor 4 expression in vascular smooth muscle cells. Brain Res. 2010;1322:102-8

141. Dasu MR, Park S, Devaraj S, Jialal I. Pioglitazone inhibits toll-like receptor expression and activity in human monocytes and $\mathrm{db} / \mathrm{db}$ mice. Endocrinology. 2007:150:3457-64.

142. Wu Y, Tang K, Huang R-Q, Zhuang Z, Cheng H-L, Yin H-X, et al. Therapeutic potential of peroxisome proliferator-activated receptor gamma agonist rosiglitazone in cerebral vasospasm after a rat experimental subarachnoid hemorrhage model. J Neurol Sci. 2011;305:85-91.

143. Wu L-Y, Ye Z-N, Zhou C-H, Wang C-X, Xie G-B, Zhang X-S, et al. Roles of pannexin-1 channels in inflammatory response through the tlrs/nf-kappa $b$ signaling pathway following experimental subarachnoid hemorrhage in rats. Front Mol Neurosci. 2017;10:175.

144. Henke PK, Mitsuya M, Luke CE, Elfline MA, Baldwin JF, Deatrick KB, et al. Tolllike receptor 9 signaling is critical for early experimental deep vein thrombosis resolution. Arterioscler Thromb Vasc Biol. 2011:31:43-9.

145. Leao AA. Spreading depression of activity in the cerebral cortex. J Neurophysiol. 1944;7:359-90.

146. Gorji A. Spreading depression: a review of the clinical relevance. Brain Res Rev. 2001;38:33-60.

147. Dreier JP. The role of spreading depression, spreading depolarization and spreading ischemia in neurological disease. Nat Med. 2011;17:439.

148. Fabricius M, Fuhr S, Willumsen L, Dreier JP, Bhatia R, Boutelle MG, et al. Association of seizures with cortical spreading depression and peri-infarct depolarisations in the acutely injured human brain. Clin Neurophysiol. 2008; 119:1973-84.

149. Mayevsky A, Doron A, Manor T, Meilin S, Zarchin N, Ouaknine GE. Cortical spreading depression recorded from the human brain using a multiparametric monitoring system. Brain Res. 1996;740:268-74.
150. Chung DY, Oka F, Ayata C. Spreading depolarizations: a therapeutic target against delayed cerebral ischemia after subarachnoid hemorrhage. Journa of clinical neurophysiology: official publication of the American Electroencephalographic Society. 2016:33:196.

151. Hartings JA, Bullock MR, Okonkwo DO, Murray LS, Murray GD, Fabricius M, et al. Spreading depolarisations and outcome after traumatic brain injury: a prospective observational study. The Lancet Neurology. 2011;10:1058-64.

152. Leo AA. Pial circulation and spreading depression of activity in the cerebral cortex. J Neurophysiol. 1944;7:391-6.

153. Hansen AJ, Quistorff B, Gjedde A. Relationship between local changes in cortical blood flow and extracellular k+ during spreading depression. Acta Physiol Scand. 1980;109:1-6.

154. Shibata M, Leffler C, Busija D. Cerebral hemodynamics during cortical spreading depression in rabbits. Brain Res. 1990;530:267-74.

155. Feuerstein D, Backes $H$, Gramer M, Takagaki M, Gabel P, Kumagai T, et al. Regulation of cerebral metabolism during cortical spreading depression. J Cereb Blood Flow Metab. 2016;36:1965-77.

156. Mies G, Paschen W. Regional changes of blood flow, glucose, and atp content determined on brain sections during a single passage of spreading depression in rat brain cortex. Exp Neurol. 1984;84:249-58.

157. lijima T, Mies G, Hossmann K-A. Repeated negative dc deflections in rat cortex following middle cerebral artery occlusion are abolished by mk801: Effect on volume of ischemic injury. J Cereb Blood Flow Metab. 1992;12:727-33

158. Takano T, Tian G-F, Peng W, Lou N, Lovatt D, Hansen AJ, et al. Cortical spreading depression causes and coincides with tissue hypoxia. Nat Neurosci. 2007;10:754

159. Woitzik J, Hecht N, Pinczolits A, Sandow N, Major S, Winkler MK, et al. Propagation of cortical spreading depolarization in the human cortex after malignant stroke. Neurology. 2013;80:1095-102.

160. Bosche B, Graf R, Ernestus R, Dohmen C, Reithmeier T, Brinker G, et al. Members of the cooperative study of brain injury d. 2010. Recurrent spreading depolarizations after subarachnoid hemorrhage decreases oxygen availability in human cerebral cortex. Ann Neurol. 2010;67:607-17.

161. Mies G, lijima T, Hossmann K. Correlation between peri-infarct dc shifts and ischaemic neuronal damage in rat. Neuroreport. 1993;4:709-11.

162. Takano K, Latour LL, Formato JE, Carano RA, Helmer KG, Hasegawa Y, et al. The role of spreading depression in focal ischemia evaluated bv dffusion mapping. Annals of Neurology: Official Journal of the American Neurological Association and the Child Neurology Society. 1996;39:308-18.

163. Strong AJ, Anderson PJ, Watts HR, Virley DJ, Lloyd A, Irving EA, et al. Periinfarct depolarizations lead to loss of perfusion in ischaemic gyrencephalic cerebral cortex. Brain. 2007;130:995-1008.

164. Sarrafzadeh A, Santos E, Wiesenthal D, Martus P, Vajkoczy P, Oehmchen M, et al. Cerebral glucose and spreading depolarization in patients with aneurysmal subarachnoid hemorrhage. Cerebral vasospasm: Neurovascular events after subarachnoid hemorrhage. Springer; 2013:143-147.

165. Dreier JP, Major S, Pannek H-W, Woitzik J, Scheel M, Wiesenthal D, et al. Spreading convulsions, spreading depolarization and epileptogenesis in human cerebral cortex. Brain. 2011;135:259-75.

166. Gursoy-Ozdemir Y, Qiu J, Matsuoka N, Bolay H, Bermpohl D, Jin H, et al. Cortical spreading depression activates and upregulates $\mathrm{mmp}-9$. J Clin Invest. 2004:113:1447-55.

167. Takizawa T, Qin T, Lopes de Morais A, Sugimoto K, Chung JY, Morsett L, et al. Non-invasively triggered spreading depolarizations induce a rapid proinflammatory response in cerebral cortex. Journal of Cerebral Blood Flow \& Metabolism. 2019:0271678X19859381.

168. Kunkler PE, Hulse RE, Kraig RP. Multiplexed cytokine protein expression profiles from spreading depression in hippocampal organotypic cultures. J Cereb Blood Flow Metab. 2004:24:829-39.

169. Urbach A, Bruehl C, Witte OW. Microarray-based long-term detection of genes differentially expressed after cortical spreading depression. Eur J Neurosci. 2006;24:841-56.

170. Berger M, Speckmann E, Pape H, Gorji A. Spreading depression enhances human neocortical excitability in vitro. Cephalalgia. 2008;28:558-62.

171. Urbach A, Baum E, Braun F, Witte OW. Cortical spreading depolarization increases adult neurogenesis, and alters behavior and hippocampusdependent memory in mice. J Cereb Blood Flow Metab. 2017:37:1776-90.

172. Yanamoto H, Miyamoto S, Tohnai N, Nagata I, Xue J-H, Nakano Y, et al. Induced spreading depression activates persistent neurogenesis in the subventricular zone, generating cells with markers for divided and early 
committed neurons in the caudate putamen and cortex. Stroke. 2005; 36:1544-50.

173. Oliveira-Ferreira Al, Milakara D, Alam M, Jorks D, Major S, Hartings JA, et al. Experimental and preliminary clinical evidence of an ischemic zone with prolonged negative dc shifts surrounded by a normally perfused tissue belt with persistent electrocorticographic depression. J Cereb Blood Flow Metab. 2010;30:1504-19

174. Herdegen T, Sandkühler J, Gass P, Kiessling M, Bravo R, Zimmermann M. Jun, fos, krox, and creb transcription factor proteins in the rat cortex: basal expression and induction by spreading depression and epileptic seizures. J Comp Neurol. 1993;333:271-88.

175. Akins PT, Liu PK, Hsu CY. Immediate early gene expression in response to cerebral ischemia: Friend or foe? Stroke. 1996;27:1682-7.

176. Herrera DG, Robertson HA. Activation of c-fos in the brain. Prog Neurobiol. 1996:50:83-107.

177. Sharp FR, Sagar SM. Alterations in gene expression as an index of neuronal injury: geat shock and the immediate early gene response. Neurotoxicology. 1994;15:51-9.

178. Plumier J-CL, David J-C, Robertson HA, Currie RW. Cortical application of potassium chloride induces the low-molecular weight heat shock protein (hsp27) in astrocytes. J Cereb Blood Flow Metab. 1997;17:781-90.

179. Thompson CS, Hakim AM. Cortical spreading depression modifies components of the inflammatory cascade. Mol Neurobiol. 2005:32:51-7.

180. Yi J-H, Park S-W, Kapadia R, Vemuganti R. Role of transcription factors in mediating post-ischemic cerebral inflammation and brain damage. Neurochem Int. 2007;50:1014-27.

181. Miettinen S, Fusco FR, Yrjänheikki J, Keinänen R, Hirvonen T, Roivainen R, et al. Spreading depression and focal brain ischemia induce cyclooxygenase-2 in cortical neurons through n-methyl-d-aspartic acidreceptors and phospholipase a2. Proc Natl Acad Sci. 1997;94:6500-5.

182. Varga DP, Puskás T, Menyhárt Á, Hertelendy P, Zölei-Szénási D, Tóth $R$, et al. Contribution of prostanoid signaling to the evolution of spreading depolarization and the associated cerebral blood flow response. Sci Rep 2016;6:1-10

183. Eising E, Shyti R, AC't Hoen P, Vijfhuizen LS, Huisman SM, Broos LA, et al. Cortical spreading depression causes unique dysregulation of inflammatory pathways in a transgenic mouse model of migraine. Mol Neurobiol. 2017;54: 2986-96.

184. Grinberg YY, Dibbern ME, Levasseur VA, Kraig RP. Insulin-like growth factor-1 abrogates microglial oxidative stress and tnf-a responses to spreading depression. J Neurochem. 2013;126:662-72.

185. Malkov A. Ivanov Al, Popova I, Mukhtarov M, Gubkina O, Waseem T, et al. Reactive oxygen species initiate a metabolic collapse in hippocampal slices: potential trigger of cortical spreading depression. J Cereb Blood Flow Metab. 2014;34:1540-9.

186. Smith JA, Park S, Krause JS, Banik NL. Oxidative stress, DNA damage, and the telomeric complex as therapeutic targets in acute neurodegeneration. Neurochem Int. 2013;62:764-75.

187. Jander S, Schroeter M, Peters O, Witte OW, Stoll G. Cortical spreading depression induces proinflammatory cytokine gene expression in the rat brain. J Cereb Blood Flow Metab. 2001;21:218-25.

188. Chang R, Hudson P, Wilson B, Liu B, Abel H, Hong J. High concentrations of extracellular potassium enhance bacterial endotoxin lipopolysaccharideinduced neurotoxicity in glia-neuron mixed cultures. Neuroscience. 2000;97: $757-64$

189. Kraig RP, Mitchell HM, Christie-Pope B, Kunkler PE, White DM, Tang Y-P, et al. Tnf-a and microglial hormetic involvement in neurological health \& migraine. Dose-Response. 2010;8:389-413.

190. Levy D. Endogenous mechanisms underlying the activation and sensitization of meningeal nociceptors: the role of immuno-vascular interactions and cortical spreading depression. Curr Pain Headache Rep. 2012;16:270-7.

191. Jiang M, Yu S, Yu Z, Sheng H, Li Y, Liu S, et al. Xbp1 (x-box-binding protein1)-dependent o-glcnacylation is neuroprotective in ischemic stroke in young mice and its impairment in aged mice is rescued by thiamet-g. Stroke. 2017:48:1646-54.

192. Yilmaz E, Akar R, Eker ST, Deda G, Adiguzel Y, Akar N. Relationship between functional promoter polymorphism in the xbp1 gene $(-116 \mathrm{c} / \mathrm{g})$ and atherosclerosis, ischemic stroke and hyperhomocysteinemia. Mol Biol Rep. 2010:37.269-72
193. Karatas H, Erdener SE, Gursoy-Ozdemir Y, Lule S, Eren-Koçak E, Sen ZD, et al. Spreading depression triggers headache by activating neuronal panx 1 channels. Science. 2013;339:1092-5.

194. Kimura H, Gules I, Meguro T, Zhang JH. Cytotoxicity of cytokines in cerebral microvascular endothelial cell. Brain Res. 2003;990:148-56.

195. Takizawa T, Shibata M, Kayama Y, Toriumi H, Ebine T, Koh A, et al. Temporal profiles of high-mobility group box 1 expression levels after cortical spreading depression in mice. Cephalalgia. 2016;36:44-52.

196. Liddelow SA, Barres BA. Reactive astrocytes: production, function, and therapeutic potential. Immunity. 2017;46:957-67.

197. Sukhotinsky I, Dilekoz E, Wang Y, Qin T, Eikermann-Haerter K, Waeber C, et al. Chronic daily cortical spreading depressions suppress spreading depression susceptibility. Cephalalgia. 2011:31:1601-8.

198. Hirsch EC, Hunot S. Neuroinflammation in parkinson's disease: a target for neuroprotection? The Lancet Neurology. 2009:8:382-97.

199. Zhang X, Ha T, Lu C, Lam F, Liu L, Schweitzer J, et al. Poly (i: C) therapy decreases cerebral ischaemia/reperfusion injury via tIr 3-mediated prevention of fas/fadd interaction. J Cell Mol Med. 2015;19:555-65.

200. Wang P-F, Fang H, Chen J, Lin S, Liu Y, Xiong X-Y, et al. Polyinosinicpolycytidylic acid has therapeutic effects against cerebral ischemia/ reperfusion injury through the downregulation of tru signaling via t|r3. J Immunol. 2014;192:4783-94.

201. Ghaemi A, Sajadian A, Khodaie B, Lotfinia AA, Lotfinia M, Aghabarari A, et al. Immunomodulatory effect of toll-like receptor-3 ligand poly i: $\mathrm{C}$ on cortical spreading depression. Mol Neurobiol. 2016;53:143-54.

\section{Publisher's Note}

Springer Nature remains neutral with regard to jurisdictional claims in published maps and institutional affiliations.
Ready to submit your research? Choose BMC and benefit from:
- fast, convenient online submission
- thorough peer review by experienced researchers in your field
- rapid publication on acceptance
- support for research data, including large and complex data types
- gold Open Access which fosters wider collaboration and increased citations
- maximum visibility for your research: over $100 \mathrm{M}$ website views per year
At BMC, research is always in progress.
Learn more biomedcentral.com/submissions 